\title{
HUBUNGAN ANTARA TINGKAT PENGETAHUAN DAN PELAKSANAAN SENAM NIFAS DENGAN KECEPATAN PROSES INVOLUSI UTERUS
}

\author{
Nyna Puspitaningrum \\ Dosen Program Studi D-III Kebidanan Universitas PGRI Adi Buana Surabaya
}

\begin{abstract}
At the time of pregnancy and delivery ligaments, pelvis diaphragm and facia were tightly stretched, eventually rotundum became loose and cause the uterus fall backward. To recover the tissue a post natal exercises need to be done. By doing the post natal exercise enabled the stretching of muscle tone of the abdominal and perineum, recover the venous pelvic, increase the uterus contraction that can smoothly passed of the lochea and speed up involution process. The aim of research was to analyze the relation between the phase of post natal knowledge and exercises with the velocity involution of the uterus. The research applied a Quasy Experiment design. Populations involved in this research were all physiologist post natal in $R B / K I A$ "Endang" in Sidoarjo July 2010. The samples were collected using consecutive sampling, to analyze the relation between variables, used Chi Square test. The result showed that there was a correlation between post natal knowledge and exercises with the velocity of uterus involution where of $p=0,000>\alpha=0,05$ so there is a need to increase health promotion means about post natal exercises, hence forth post natal exercise helped post partum mother to regain their condition.
\end{abstract}

Keywords: Knowledge, Post natal exercises, involution of the uterus

\section{PENDAHULUAN}

Berdasar penelitian World Health Organization (WHO) diseluruh dunia terdapat kematian ibu dan bayi sebesar 500.000 jiwa pertahun. Penyebab langsung kematian ibu di Indonesia seperti halnya di negara lain adalah perdarahan 60-70\%, eklamsia 10-20\%, infeksi 10-20\% (Manuaba, 2001). Menurut SKRT,2001 penyebab langsung kematian ibu yaitu perdarahan $28 \%$ dan infeksi $11 \%$. Sedangkan berdasarkan laporan rutin PWS KIA tahun 2007 penyebab kematian ibu adalah karena perdarahan 39\%, infeksi 7\%, dan lain-lain 33\%. (Sulistyawati A \& Esti N, 2010) Di Indonesia menurut survey Demografi Kesehatan

Indonesia 1997 Angka Kematian Ibu 334 :100.000 kelahiran hidup, untuk penurunan angka kematian ini dirasakan sangat lamban, sedangkan target tahun 2010, 125 :100.000 kelahiran hidup.

Perdarahan post partum ada kalanya merupakan perdarahan yang hebat dan menakutkan sehingga dalam waktu sangat singkat ibu dapat jatuh kedalam keadaan syok. Atau dapat berupa perdarahan yang menetes perlahan-lahan tetapi terus menerus yang juga berbahaya karena kita tidak menyangka akhirnya perdarahan berjumlah banyak, ibu menjadi lemas dan juga jatuh dalam subsyok atau syok. (Mochtar,2000;301). Perdarahan salah satu penyebabnya adalah atonia uteri sebagai dampak dari kelemahan kontraksi uterus atau kelemahan ibu, sedangkan sepsis sebagai dampak dari persalinan yang lama.

Masa nifas merupakan waktu yang diperlukan untuk mengembalikan organ reproduksi setelah persalinan dan kembali seperti kondisi sebelum hamil. Proses pemulihan kesehatan pada masa nifas merupakan hal yang sangat penting bagi ibu setelah melahirkan. Pada saat kehamilan dan persalinan, ligamen - ligamen dan diafragma pelvis serta fasia meregang. Tidak jarang ligamen rotundum menjadi kendor yang mengakibatkan uterus jatuh kebelakang. Tidak jarang pula wanita mengeluh "kandungannya turun" setelah melahirkan oleh karena ligamen, fasia, jaringan penunjang alat genetalia menjadi agak kendor. 
Untuk memulihkan kembali jaringanjaringan penunjang alat genetalia tersebut, juga otot-otot dinding perut dan dasar panggul dianjurkan untuk melakukan latihanlatihan tertentu. Keuntungan lain dari latihan-latihan ini ialah dapat dicegahnya statis darah yang dapat mengakibatkan trombosis pada masa nifas (Sarwono,2002;239). Sedangkan kerugian bila tidak melakukan senam nifas adalah dapat terjadi sub involusio, febris puerpuralis, kelemahan otot dasar panggul. Untuk menguatkan kembali otot-otot dasar panggul setelah persalinan dan memulihkan kembali kondisi seperti sebelumnya dapat dibantu dengan melaksanakan senam nifas secara teratur (Sweet,1993;247). Selain mempercepat pemulihan, senam nifas juga dapat mencegah terjadinya perdarahan pasca bersalin (Sarwono,2002;239).

Berdasarkan uraian diatas, maka dengan dilaksanakannya senam nifas pada ibu pasca bersalin diharapkan dapat membantu mengembalikan kondisi ibu seperti sebelumnya dan meningkatkan kontraksi uterus yang lemah, sehingga dapat mengurangi angka kejadian perdarahan pada ibu pasca bersalin dan dapat membantu menurunkan angka kematian ibu. Sehingga dapat ditarik suatu rumusan masalah yakni apakah ada hubungan antara tingkat pengetahuan, pelaksanaan senam nifas dengan kecepatan proses involusi uterus ? Tujuan umum penelitian adalah mengetahui hubungan antara tingkat pengetahuan, senam nifas, dengan kecepatan proses involusi uterus. Tujuan Khusus adalah 1.) Mengidentifikasi tingkat pengetahuan ibu tentang senam nifas; 2.) Mengidentifikasi "bagaimana pelaksanaan senam nifas" bagi ibu post partum; 3.) Mengidentifikasi hubungan antara tingkat pengetahuan ibu post partum tentang senam nifas dengan pelaksanaan senam nifas; 4.) Mengidentifikasi hubungan antara pelaksanaan senam nifas dengan kecepatan proses involusi uterus.

\section{BAHAN DAN METODE}

Desain penelitian yang digunakan adalah Quasy Experimental, dimana rancangan penelitian untuk mencari hubungan sebab akibat dari variabel independen dan dependen dengan cara memberikan perlakuan kepada kelompok eksperimen kemudian hasil (akibat) dari intervensi tersebut dibandingkan dengan kelompok yang tidak dikenakan perlakuan (kelompok kontrol) (Notoatmodjo, 2002;156). Populasi dalam penelitian ini adalah semua ibu post partum fisiologis yang dirawat di RB/KIA "Endang", Sidoarjo, selama bulan Mei, Juni,dan Juli 2010 dan diambil ratarata per bulan yang dalam penelitian ini responden yang senam dan tidak senam berjumlah 72 orang. Jenis responden ada dua macam yaitu yang ikut senam nifas dan yang tidak ikut senam nifas. Pengambilan sampel dilakukan secara consecutive sampling, untuk menganalisa hubungan antara variabel digunakan uji Chi Square.

Penelitian menggunankan instrumen berupa kuesioner yang terdiri atas 5 pertanyaan Data yang dikumpulkan adalah berupa data demografi (umur, pendidikan, pengetahuan, pekerjaan) dan data khusus berisi pemeriksaan oleh petugas tentang tinggi Fundus Uteri, Kontaksi uterus dan pengeluaran lochea.

Tabel 1 Distribusi responden berdasar pelaksanaan senam nifas di RB/KIA "Endang" Sidoarjo, Juli 2010

\begin{tabular}{|c|c|c|c|c|c|c|}
\hline \multirow{2}{*}{$\begin{array}{c}\text { Pelaksanaan } \\
\text { senam nifas }\end{array}$} & \multicolumn{2}{|c|}{ Senam } & \multicolumn{2}{c|}{$\begin{array}{c}\text { Tidak } \\
\text { senam }\end{array}$} & \multicolumn{2}{c|}{ Jumlah } \\
\cline { 2 - 7 } & $\mathbf{f}$ & $\%$ & $\mathbf{f}$ & $\%$ & $\mathbf{f l}$ & $\%$ \\
\hline $\begin{array}{l}\text { Tidak } \\
\text { sesuai parameter }\end{array}$ & 12 & 33,3 & 36 & 100 & 48 & 66,7 \\
\hline Sesuai parameter & 24 & 66,7 & 0 & 0 & 24 & 33,3 \\
\hline \multicolumn{1}{c|}{ Jumlah } & 36 & 100 & 36 & 100 & 72 & 100 \\
\hline
\end{tabular}

Dari tabel 1 terlihat jumlah responden yang melakukan senam nifas tidak sesuai parameter sebanyak 12 orang (33,3\%), sesuai parameter 24 orang $(66,7 \%)$. Sedangkan 36 orang (100\%) adalah kelompok tidak senam. 
Tabel 2 Distribusi responden berdasar kecepatan involusi di RB/KIA "Endang" Sidoarjo, Juli 2010

\begin{tabular}{|c|c|c|c|c|c|c|}
\hline \multirow{2}{*}{$\begin{array}{c}\text { Lama } \\
\text { Involusi }\end{array}$} & \multicolumn{2}{|c|}{ Senam } & \multicolumn{2}{c|}{$\begin{array}{c}\text { Tidak } \\
\text { senam }\end{array}$} & \multicolumn{2}{c|}{$\Sigma$} \\
\cline { 2 - 7 } & $\mathbf{f}$ & $\%$ & $\mathbf{f}$ & $\%$ & $\mathbf{f}$ & $\%$ \\
\hline$>10$ hari & 12 & 33,3 & 27 & 75 & 39 & 54,1 \\
\hline$\leq 10$ hari & 24 & 66,7 & 9 & 25 & 33 & 45,9 \\
\hline Jumlah & 36 & 100 & 36 & 100 & 72 & 100 \\
\hline
\end{tabular}

Dari tabel 2 terlihat responden yang melakukan senam nifas proses involusi uterus $>10$ hari 12 orang $(33,3 \%), \leq 10$ hari 24 orang $(66,7 \%)$. Kelompok tidak senam involusi uterus $>10$ hari 27 orang $(75 \%)$, $\leq$ 10 hari 9 orang $(25 \%)$.

Tabel 3 Distribusi responden berdasar involusi uterus di RB/KIA "Endang" Sidoarjo, Juli 2004

\begin{tabular}{|l|c|c|c|c|c|c|}
\hline \multirow{2}{*}{ Involusi uterus } & \multicolumn{2}{|c|}{ Senam } & \multicolumn{2}{|c|}{$\begin{array}{l}\text { Tidak } \\
\text { senam }\end{array}$} & \multicolumn{2}{|c|}{ I } \\
\cline { 2 - 7 } & f & $\%$ & f & $\%$ & f & $\%$ \\
\hline $\begin{array}{l}\text { Tidak sesuai } \\
\text { parameter }\end{array}$ & 9 & 25 & 26 & 72,2 & 35 & 48,7 \\
\hline $\begin{array}{l}\text { Sesuai } \\
\text { parameter }\end{array}$ & 27 & 75 & 10 & 27,8 & 37 & 51,3 \\
\hline \multicolumn{1}{|c|}{ Jumlah } & 36 & 100 & 36 & 100 & 72 & 100 \\
\hline
\end{tabular}

Dari tabel 3 terlihat bahwa responden yang melakukan senam nifas involusi uterus tidak sesuai parameter 9 orang (25\%), sesuai parameter 27 orang (75\%), Responden yang tidak melakukan senam nifas involusi uterus tidak sesuai parameter 26 orang $(72,2 \%)$, sesuai parameter 10 orang $(27,8 \%)$.

\section{HASIL DAN PEMBAHASAN}

\section{Karakteristik responden di RB/KIA "Endang " \\ Karakteristik responden yang} terdapat pada RB/KIA "Endang " adalah : 1.) Wanita post partum dengan rentang usia 2030 tahun; 2.) Pendidikan responden sebagian besar adalah SMU (75\%) dan sebagian perguruan tinggi (25\%); 3.) Responden yang melaksanakan senam nifas sebagian besar telah mengetahui tentang senam nifas dengan baik (57\%); 4.) Responden sebagian besar adalah ibu rumah tangga $(69,5 \%) ;$ 5.) Berdasar pelaksanaan senam nifas sebagian besar responden melaksanakan senam nifas sesuai parameter yang ditentukan $(66,7 \%)$; 6.) Karakteristik responden berdasar kecepatan involusi uterus terbanyak adalah $>10$ hari $(54,1 \%)$; 7.) Karakteristik responden yang melakukan senam nifas, involusi uterus sebagian besar sesuai parameter yang dibuat peneliti dibandingkan dengan yang tidak melakukan senam nifas, yakni pada hari ke-10 tinggi fundus uteri sulit teraba diatas symphisis, lochea berwarna kuning, cairan tidak berdarah lagi (75\%).

\section{Hubungan Tingkat Pengetahuan Dan Pelaksanaan Senam Nifas}

Dari hasil tabulasi silang antara tingkat pengetahuan dan pelaksanaan senam nifas didapatkan tingkat pengetahuan kurang dan pelaksanaan senam nifas tidak sesuai parameter 9 responden (75\%), 3 responden $(12,5 \%)$ pelaksanaan senam sesuai parameter. Sedangkan responden dengan pengetahuan baik pelaksanaan senam nifas tidak sesuai parameter 3 responden (25\%) dan sesuai parameter sebanyak 21 responden (87,5\%).

Dari hasil uji statistik Chi Square didapatkan $\mathrm{p}=0,00<\alpha=0,05$ sehingga $\mathrm{HO}$ ditolak berarti ada hubungan yang bermakna antara tingkat pengetahuan dengan pelaksanaan senam nifas. Menurut Notoatmodjo (2002) pengetahuan atau kognitif merupakan domain sangat penting untuk terbentuknya tindakan seseorang dan dari pengalaman ternyata perilaku didasari oleh pengetahuan.

Faktor lain, adanya motivasi. Menurut Ngalim,P (1999) motivasi merupakan salah satu usaha yang disadari untuk mempengaruhi tingkah laku seseorang untuk bertindak melakukan sesuatu sehingga mencapai tujuan tertentu. 
Tabel 4 Hubungan antara tingkat pengetahuan senam nifas dengan pelaksanaan senam nifas

\begin{tabular}{|c|c|c|c|c|c|c|}
\hline \multirow{2}{*}{$\begin{array}{c}\text { Pengetahuan } \\
\text { tentang } \\
\text { senam } \\
\text { nifas }\end{array}$} & \multicolumn{4}{|c|}{ Pelaksanaan senam nifas } & \multicolumn{2}{|c|}{$\Sigma$} \\
\hline & $\begin{array}{c}\text { Tidak } \\
\text { sesuai } \\
\text { parameter }\end{array}$ & $\%$ & $\begin{array}{c}\text { Sesuai } \\
\text { parameter }\end{array}$ & $\%$ & $\Sigma$ & $\%$ \\
\hline Kurang & 9 & 75 & 3 & 12,5 & 12 & 33,3 \\
\hline Baik & 3 & 25 & 21 & 87,5 & 24 & 66,7 \\
\hline Jumlah & 12 & 100 & 24 & 100 & 36 & 100 \\
\hline
\end{tabular}

Dari tabel 4 menunjukkan bahwa responden dengan pengetahuan kurang sebanyak 9 orang $(75 \%)$ melaksanakan senam nifas tidak sesuai parameter, 3 orang $(12,5 \%)$ sesuai parameter. Sedangkan responden dengan pengetahuan baik pelaksanaan senam nifas tidak sesuai parameter 3 orang (25\%) dan sesuai parameter sebanyak 21 orang (87,5\%). Hasil Uji Statistik Chl Square $p=0,00<\alpha=0,05$ sehingga $\mathrm{HO}$ ditolak berarti ada hubungan yang bermakna antara tingkat pengetahuan dengan pelaksanaan senam nifas.

\section{Hubungan Pelaksanaan Senam Nifas Dan Kecepatan Proses Involusi Uterus.}

Dari hasil tabulasi silang antara pelaksanaan senam nifas dengan kecepatan proses involusi uterus didapatkan yang melaksanakan senam nifas tidak sesuai parameter dan involusi uterus $>10$ hari 12 responden (100\%), sesuai parameter dan involusi uterus $\leq 10$ hari 24 responden (100\%), sedangkan- kelompok yang tidak melakukan senam nifas involusi uterus $>10$ hari 27 orang $(100 \%), \leq 10$ hari sebanyak 9 orang (100\%).

Dari hasil Uji Chi Square didapatkan $\mathrm{p}=0,00<\alpha=0,05$ sehingga $\mathrm{HO}$ ditolak berarti ada hubngan yang bermakna antara pelaksanaan senam nifas dengan kecepatan proses involusi uterus.

Menurut Manuaba (2001), dengan melakukan senam nifas akan memenuhi kebutuhan otot-otot terhadap oksigen, yang mana kebutuhan oksigen meningkat berarti memerlukan aliran darah yang kuat.

Pada ibu nifas kontraksi uterus yang baik akan mempercepat proses involusi uterus. Bila otot-otot rahim dirangsang kontraksinya dengan melakukan senam nifas maka aliran darah akan meningkat dan lancar, kontraksi uterus semakin baik, pengeluaran lochea menjadi lancar, sehingga mempengaruhi pengecilan rahim (Manuaba;2001).

Tabel 5 Hubungan antara pelaksanaan senam nifas dengan kecepatan involusi uterus

\begin{tabular}{|c|c|c|c|c|c|c|c|c|c|c|}
\hline \multirow{2}{*}{$\begin{array}{c}\text { Pelaksanaan } \\
\text { senam nifas }\end{array}$} & \multicolumn{9}{|c|}{ Kecepatan involusi uterus } & \multicolumn{3}{c|}{ Tidak Senam } \\
\cline { 2 - 11 } \\
\cline { 2 - 11 } & $\begin{array}{c}>10 \\
\text { hari }\end{array}$ & $\%$ & $\begin{array}{c}\leq 10 \\
\text { hari }\end{array}$ & $\%$ & $\begin{array}{c}>10 \\
\text { hari }\end{array}$ & $\%$ & $\begin{array}{c}\leq 10 \\
\text { hari }\end{array}$ & $\%$ & $\sum$ & $\%$ \\
\hline $\begin{array}{l}\text { Tidak } \\
\text { sesuai } \\
\text { parameter }\end{array}$ & 12 & 100 & 0 & 0 & 27 & 100 & 0 & 0 & 39 & 54,1 \\
\hline $\begin{array}{l}\text { Sesuai } \\
\text { parameter }\end{array}$ & 0 & 0 & 24 & 100 & 0 & 0 & 9 & 100 & 33 & 45,9 \\
\hline Jumlah & 12 & 100 & 24 & 100 & 27 & 100 & 9 & 100 & 72 & 100 \\
\hline
\end{tabular}

Dari tabel 5 diatas terlihat bahwa yang melaksanakan senam nifas tetapi tidak sesuai parameter involusi uterus $>10$ hari sebanyak 12 orang (100\%), sesuai parameter involusi uterus $\leq 10$ hari 24 orang $(100 \%)$, sedangkan kelompok yang tidak melakukan senam nifas involusi uterus $>10$ hari 27 orang $(100 \%), \leq 10$ hari sebanyak 9 orang (100\%). Hasil Uji Statistik Chi Square $\mathrm{p}=0,00<\alpha=0,05$ sehingga $\mathrm{HO}$ ditolak berarti ada hubungan yang bermakna antara pelaksanaan senam nifas dengan kecepatan proses involusi uterus.

\section{SIMPULAN DAN SARAN}

Berdasarkan data analisis maka dapat disimpulkan sebagai berikut : 1.) Pengetahuan ibu post partum tentang senam nifas di RB/KIA "Endang" Sidoarjo sebagian besar adalah berpengetahuan baik; 2.) Pelaksanaan senam nifas ibu post partum fisiologis di RB/KIA "Endang" Sidoarjo yang melaksanakan senam

nifas sesuai dengan parameter lebih banyak dari ibu yang melaksanakan senam nifas tidak sesuai parameter; 3.) Ada hubungan yang bermakna antara pengetahuan tentang senam nifas dengan pelaksanaan senam nifas pada ibu post partum fisiologis di RB/KIA "Endang" Sidoarjo; 4.) Ada hubungan yang bermakna antara pelaksanaan senam nifas dengan kecepatan proses involusi uterus pada ibu post partum fisiologis di RB/KIA "Endang" Sidoarjo.

Berdasarkan hasil penelitian diharapkan bagi masyarakat khususnya bagi ibu-ibu yang tidak beresiko dan seijin dokter atau bidan sebaiknya mengikuti latihan fisik senam nifas, karena dengan mengikuti senam nifas dapat membantu memulihkan kembali otot-otot yang kendor saat kehamilan dan persalinan juga mempercepat proses involusi uterus sehingga 
membantu mempercepat pengembalian kondisi ibu seperti semula, bagi institusi kesehatan dirasakan sangat perlu untuk mempromosikan senam nifas di masyarakat dengan pemasangan poster yang menarik agar diketahui pengunjung, sehingga bagi ibu post partum dapat tertarik untuk mengikuti senam nifas. Serta dapat memberikan Health Education bagi ibu post partum dan keluarga tentang manfaat senam nifas serta memberikan motivasi dan dukungan secara moril agar ibu post partum tertarik dan mau mengikuti senam nifas.

\section{DAFTAR ACUAN}

Danuatmaja (2003), 40 hari pasca Persalinan, Jakarta. Puspa Swara

Jackson,L (1998), Bugar Menjelang Melahirkan, Jakarta.Arcan

Manuaba,IBG (1999), Memahami Kesehatan Reproduksi Wanita,Jakarta,Arcan

Manuaba,IBG (2001),IImu Kebidanan, Penyakit Kandungan, dan KB, Jakarta EGC
Mochtar,M (2000), Sinopsis Obstetri I,Jakarta EGC

Mochtar,M (2000), Sinopsis Obstetri II,Jakarta EGC

Maulany (1998),Pencegahan Kematian Ibu Hamil, Jakarta.Binarupa Aksara

Ngalim.P,MP,(1999), Psikologi Pendidikan,Jakarta.PT.Remaja Rusta Karya

Notoatmodjo,S (1997), IImu Kesehatan Masyarakat, Jakarta.PT.Rineka Cipta

Notoatmodjo,S (2002),Metode Penelitian Kesehatan, Jakarta. PT.Rineka Cipta

Purnomo,W (2003), Pengantar Metodologi Riset Kuantitatif Untuk Karya Tulis IImiah Bidang Kebidanan, Surabaya.Airlangga

Sweet (1993), A Texbook For Midwifes, Philadelphia.WB Saundes 